\title{
Faktor Penyebab Kurangnya Minat Anak Keluarga Nelayan Melanjutkan Pendidikan ke Perguruan Tinggi di Desa Puger Kulon Kecamatan Puger
}

\author{
Shendy Andrie Wijaya*1, David K. Susilo², Devi Septiani Ratna Sari ${ }^{3}$ \\ 1,2,3 Program Studi Pendidikan Ekonomi \\ Universitas PGRI Argopuro \\ Jember, Indonesia \\ e-mail: shendyandriewijaya@gmail.com*1
}

Riwayat Artikel Tanggal diajukan: 10 November 2021

Tanggal diterima : 5 Desember 2021

Tanggal dipublikasikan: 15 Desember 2021
Pengutipan:

Wijaya, S. A., Susilo, D. K. \& Sari, D. S. R. (2021). Faktor Penyebab

Kurangnya Minat Anak Keluarga Nelayan

Melanjutkan Pendidikan ke

Perguruan Tinggi Di Desa Puger Kulon Kecamatan Pugor. Jurnal. Pendidikan

Ekonomi

Undiksha, 13(2), 422-427.

http://dx.doi.org/1 $0.23887 /$ ijpe v13 2.42309

\begin{abstract}
Abstrak
Penelitian ini bertujuan untuk mendeskripsikan faktor penyebab dan faktor dominan penyebab kurangnya minat anak keluarga nelayan melanjutkan pendidikan ke perguruan tinggi di Desa Puger Kulon Kecamatan Puger. Penelitian ini berjenis penelitian kualitatif deskriptif. Jumlah informan sebanyak 6 orang, pemilihan informan dalam penelitian ini menggunakan teknik purposive sampling, dengan kriteria anak keluarga nelayan yang tidak melanjutkan pendidikan ke perguruan tinggi sebagai informan utama dan orang tua anak yang bersangkutan sebagai informan pendukung. Teknik pengumpulan data yang digunakan yaitu observasi, wawancara dan dokumentasi. Analisis data dalam penelitian ini menggunakan reduksi data, penyajian data dan penarikan kesimpulan. Teknik pengabsahan data menggunakan triangulasi sumber dan tekhnik. Hasil penelitian menunjukkan bahwa: faktor penyebab kurangnya minat anak keluarga nelayan melanjutkan pendidikan ke perguruan tinggi di Desa Puger Kulon Kecamatan Puger adalah keinginan anak sendiri, faktor ekonomi keluarga, tidak ada dorongan dari orang tua, faktor lokasi, dan faktor llingkungan. Sedangkan faktor dominan penyebab kurangnya minat anak keluarga nelayan melanjutkan pendidikan ke perguruan tinggi adalah faktor ekonomi keluarga
\end{abstract}

Kata kunci: Minat; Anak Keluarga Nelayan; Desa Puger Kulon

\begin{abstract}
This study aims to describe the causative and dominant factors causing the lack of interest in fisher family children to continue their education to higher education in Puger Kulon Village, Puger District. This research is a descriptive qualitative research. The number of informants was 6 people, the selection of informants in this study used a purposive sampling technique, with the criteria of fishermen family children who did not continue their education to college as the main informants and the parents of the children concerned as supporting informants. The data collection techniques used were observation, interview and documentation. Data analysis in this study used data reduction, data presentation and drawing conclusions. Data validation techniques use source triangulation and techniques. The results showed that: the factors causing the lack of interest in the children of fishermen's families to continue their education to higher education in Puger Kulon Village, Puger District were the child's own desires, family economic factors, no encouragement from parents, location factors, and environmental factors. Meanwhile, the dominant factor causing the lack of interest in children.
\end{abstract}

Keywords: Interests; Fisherman Family Children; Puger Kulon Village 


\section{PENDAHULUAN}

Pada hakekatnya pendidikan sangat penting dan tidak bisa lepas dari kehidupan manusia. Pendidikan merupakan proses menyiapkan individu untuk menyesuaikan diri dengan lingkungan. Pendidikan berperan penting dalam pembangunan nasional, karena dengan adanya pendidikan akan terbentuk sumber daya manusia yang berkualitas. Oleh sebab itu pendidikan pada generasi muda diharapkan mampu mendukung pencapaian tujuan pembangunan nasional. Coombs (1982) mengklasifikasikan pendidikan kedalam tiga bagian yaitu pendidikan formal seperti pendidikan di Sekolah Dasar, Sekolah Menengah Pertama, Sekolah Menengah Atas, dan pendidikan di Perguruan Tinggi. Menurut Hasbullah (2012) ada beberapa faktor-faktor pendidikan, yaitu faktor tujuan, faktor pendidik, faktor anak didik, faktor alat pendidikan, faktor lingkungan. Berdasarkan Pasal 1 ayat (1) Undang-Undang Nomor 20 tahun 2003 tentang Sistem Pendidikan Nasional menjelaskan bahwa: Pendidikan adalah usaha sadar dan terencana untuk mewujudkan suasana belajar dan proses pembelajaran agar peserta didik secara aktif mengembangkan potensi dirinya untuk memiliki kekuatan spiritual keagamaan, pengendalian diri, kepribadian, kecerdasan, akhlak mulia, serta keterampilan yang diperlukan dirinya, masyarakat, bangsa dan negara (Umbara, 2003). Berdasarkan uraian di atas maka Sistem Pendidikan Nasional (SPN) sebagai usaha sadar untuk mewujudkan peserta didik aktif serta dapat menciptakan peserta didik yang memiliki kemampuan yang dapat berkontribusi langsung dalam dunia usaha. Selain mempunyai kemampuan pesera didik harus dituntut sadar akan perkembangan teknologi guna melanjutkan pendidikan keperguruan tinggi.

Melanjutkan pendidikan ke perguruan tinggi di awali dengan rasa ketertarikan untuk mengembangkan ilmu pengetahuan. Adanya minat dalam diri individu akan mendorong seseorang untuk melakukan suatu tindakan dan partisipasi didalamnya. Minat memiliki dampak yang besar dan memiliki peranan yang sangat penting dalam kehidupan seseorang atas sikap dan perilakunya. Jika seseorang berminat terhadap suatu objek maka akan berpengaruh terhadap segala sikap dan perilakunya. Misalnya seseorang yang memiliki minat tinggi, dia akan berusaha sekuat tenaga agar apa yang diinginkan mencapai suatu tujuan meskipun banyak hambatan yang akan dihadapinya. Minat dapat menjadi dasar atau landasan seseorang dalam melaksanakan suatu aktivitas, sehingga memperoleh hasil yang optimal. Minat dapat mendorong seseorang untuk melakukan perbuatan mencapai tujuannya. Hubungan minat dan tindakan sangatlah erat, seseorang tidak akan melakukan sesuatu apabila orang tersebut tidak memiliki minat terhadap objek itu.

Minat untuk melanjutkan pendidikan ke perguruan tinggi merupakan sesuatu yang sangat penting bagi pendidikan seorang anak. Minat yang tinggi dapat meningkatkan semangat anak untuk melanjutkan pendidikan yang lebih tinggi, dengan adanya minat untuk melanjutkan pendidikan ke perguruan tinggi maka dapat menumbuhkan semangat anak untuk berjuang dan memperoleh pendidikan lanjutan. Sesuai dengan pendapat Slameto (2010) mengemukakan bahwa minat adalah suatu rasa lebih suka dan rasa ketertarikan pada suatu hal atau aktivitas, tanpa ada yang menyuruh. Namun pada saat ini masih banyak permasalahan yang terjadi dalam sistem pendidikan di Indonesia. Salah satunya adalah masyarakat di daerah pesisir ternyata masih mempunyai kesadaran yang cukup rendah terhadap pentingnya pendidikan untuk anak-anak mereka sehingga banyak anak usia pendidikan yang kesulitan untuk melanjutkan sekolah atau tidak sekolah sama sekali. Pendidikan amatlah penting bagi semua kelas tak terkecuali anak-anak nelayan. Pentingnya pendidikan bagi anak nelayan terletak pada kemampuan untuk meningkatkan kecerdasan anak, serta menjadikan anakanak mereka menjadi anak yang lebih maju dibidang ilmu pengetahuan Alexander (2016). Minat anak untuk melanjutkan pendidikan ke perguruan tinggi masih rendah, minat yang rendah ditunjukan dengan masih adanya anak yang memilih untuk bekerja dibandingkan dengan 
p-ISSN : 2599-1418

e-ISSN : 2599-1426

melanjutkan pendidikan ke perguruan tinggi. Hal tersebut yang terjadi pada masyarakat nelayan puger, yang kenyataannya masih ada anak dari keluarga nelayan yang tidak melanjutkan pendidikannya ke perguruan tinggi, minat yang rendah dapat dipengaruhi oleh berbagai faktor.

Berdasarkan hasil observasi awal yang peneliti lakukan pada tanggal 06 Februari 2020, minat anak keluarga nelayan di desa Puger Kulon Kecamatan Puger untuk melanjutkan ke perguruan tinggi masih sangat rendah, minat yang rendah ditunjukan dengan masih adanya anak yang memilih untuk bekerja dibandingkan dengan melanjutkan ke perguruan tinggi karena adanya faktor yang mempengaruhinya, masyarakat beranggapan bahwa lulusan perguruan tinggi cenderung negatif karena mereka beranggapan bahwa lulus dari perguruan tinggi tidak selalu langsung mendapat pekerjaan yang mumpuni, bahkan banyak dijumpai lulusan perguruan tinggi yang menganggur. Pandangan masyarakat seperti inilah yang menyebabkan belum optimalnya minat anak untuk melanjutkan ke perguruan tinggi, sehingga mereka memilih suatu pekerjaan yang tidak membutuhkan ijasah S1 yaitu ada yang bekerja dibengkel, bekerja di pasar sebagai pelayan di toko, bahkan banyak yang ke luar kota bekerja sebagai bank keliling atau koperasi simpan pinjam, kemudian ada yang ikut orangtua nelayan.

Penelitian mengenai faktor penyebab kurangnya minat melanjutkan ke perguruan tinggi awalnya sudah pernah diteliti oleh Arnawan (2016) yang berjudul "Faktor Penyebab Kurangnya Minat Remaja Terhadap Pendidikan Di Perguruan Tinggi (Studi Pada Remaja Di Desa Balirejo Kecamatan Angkona Kabupaten Luwu Timur)." Hasil penelitian ini menunjukan, bahwa: 1) Faktor internal yang menyebabkan kurangnya minat remaja terhadap pendidikan di perguruan tinggi di Desa Balirejo adalah: (a) faktor kurangnya motivasi atau keinginan untuk kuliah, (b) keinginan untuk mandiri dengan mencari kerja setelah tamat SMA. 2) Faktor eksternal yang menyebabkan adalah: (a) faktor keterbatasan ekonomi atau biaya
Jurnal Pendidikan Ekonomi Undiksha

Vol. 13 No. 2 (2021)

pendidikan yang tinggi dan (b) faktor lingkungan dan budaya.

Selain itu Palupi (2017) yang berjudul "Analisis Deskriptif Faktor Yang Mempengaruhi Rendahnya Minat Melanjutkan Pendidikan Ke Perguruan Tinggi Pada Siswa Kelas XII SMK Negeri Karangpucung Kabupaten Cilacap." Hasil penelitian menunjukkan bahwa faktor yang paling dominan berpengaruh terhadap rendahnya minat melanjutkan pendidikan ke perguruan tinggi yaitu faktor lingkungan dan faktor yang berpengaruh rendah terhadap rendahnya minat melanjutkan pendidikan ke perguruan tinggi adalah pandangan hidup. Dari penelitian terdahulu yang dilakukan oleh Gede Arnawan dan Palupi, Elvia, Diyah dengan penelitian sekarang memiliki persamaan dalam pembahasan mengenai faktor penyebab kurangnya minat melanjutkan ke perguruan tinggi. Hal yang membedakan dari penelitian terdahulu di atas dengan penelitian ini adalah terkait tempat penelitian, analisis data yang digunakan dan informannya yaitu anak keluarga nelayan serta menambahkan faktor dominan yang menjadi penyebab kurangnya minat melanjutkan ke perguruan tinggi.

Berdasarkan permasalahan tersebut, penulis tertarik dan ingin mengetahui lebih jauh tentang faktor-faktor penyebab kurangnya minat anak keluarga nelayan melanjutkan pendidikan ke perguruan tinggi di Desa Puger Kulon Kecamatan Puger.

\section{METODE}

Penelitian ini menggunakan jenis penelitian lapangan dengan pendekatan kualitatif. Metode yang digunakan dalam penelitian ini adalah metode deskriptif. Menurut Sukardi (2007) metode deskriptif adalah metode yang digunakan untuk memecahkan masalah yang sedang dihadapi pada masa sekarang, dilakukan dengan langkah-langkah pengumpulan data dan analisa atau pengolahan data, membuat kesimpulan tentang suatu keberadaan secara obyektif dalam suatu deskriptif situasi. 
Lokasi penelitian menunjukkan tempat dimana penelitian dilakukan, karena penetapan lokasi penelitian sangat penting dalam rangka mempertanggungjawabkan data yang diperoleh. Dengan demikian lokasi penelitian perlu ditetapkan terlebih dahulu. Lokasi penelitian ini adalah Desa Puger Kulon yang berada di Kecamatan Puger, alasan peneliti mengambil lokasi ini karena mayoritas penduduknya bermata pencaharian sebagai nelayan.

Sumber data dalam penelitian ini diperoleh dari data primer dan data sekunder. Teknik pengumpulan data menggunakan observasi, wawancara dan dokumentasi. Dalam melakukan analisis dipergunakan jalan pikiran Miles \& Houberman (1992) yang menyatakan bahwa dalam melakukan proses analisis komponen utama yang perlu diperhatikan setelah pengumpulan data adalah reduksi data, penyajian data, dan menarik kesimpulan atau verifikasi.

\section{HASIL DAN PEMBAHASAN}

Pendidikan merupakan aspek yang sangat penting bagi perkembangan sumber daya manusia, salah satunya yaitu perguruan tinggi. Tetapi, melihat kondisi perguruan tinggi saat ini tidak banyak orang yang menginginkan hal itu. Hal tersebut dikarenakan minat belajar mereka yang menurun dan harapan untuk menjadi orang yang lebih maju melalui perguruan tinggi sangatlah kurang. Kesadaran mereka akan pentingnya suatu pendidikan masih sangat rendah, terbukti dengan cara mereka mempersepsikan pendidikan. Sebagian dari mereka ada yang menganggap bahwa pendidikan hanya sekedar menghabiskan uang saja. Hasil wawancara dan observasi di Desa Puger Kulon Kecamatan Puger menyatakan bahwa faktor penyebab kurangnya minat anak keluarga nelayan melanjutkan pendidikan ke perguruan tinggi yaitu:

1. Faktor-Faktor Penyebab Kurangnya Minat Anak Keluarga Nelayan Melanjutkan Pendidikan ke Perguruan Tinggi

a. Keinginan Anak Sendiri

Rendahnya kesadaran pendidikan pada anak keluarga nelayan di Desa Puger
Kulon Kecamatan Puger untuk melanjutkan ke perguruan tinggi disebabkan karena keinginannya sendiri untuk tidak mau kuliah, mereka tidak mempunyai keinginan dalam dirinya untuk melanjutkan ke perguruan tinggi. Berdasarkan hasil penelitian tersebut senada dengan pendapat Yuda dalam Taha (2013) yaitu " Keinginan remaja merupakan suatu yang berasal dari dalam diri remaja itu sendiri atau yang berasal dari dalam hati nuraninya". Hal ini dialami oleh saudari Risawatul dan Harfan Dharma.

\section{b. Faktor Ekonomi Keluarga}

Banyak orangtua yang mengharapkan dapat menyekolahkan anaknya sampai ke perguruan tinggi, mereka sadar bahwa dengan pendidikan tinggi dapat merubah kehidupan yang lebih baik, namun dengan keadaan ekonomi yang kurang mendukung, mengakibatkan Bapak Husnan selaku orang tua dari saudara Ahmad Rahman hanya dapat menyekolahkan anaknya hanya sampai tingkat SMK saja. Berdasarkan hasil penelitian tersebut sejalan dengan pendapat Saroni (2011) bahwa "Tingkat perekonomian keluarga pada kenyataannya merupakan salah satu aspek penghambat, bahkan kehilangan kesempatan proses pendidikan dan pembelajaran. Ada banyak anak usia sekolah yang terhambat, bahkan kehilangan kesempatan mengikuti proses pendidikan hanya karena keadaan ekonomi keluarga yang kurang mendukung".

c. Tidak Ada Dorongan Dari Orang Tua

$\mathrm{Hal}$ yang dialami oleh saudara Refangga, orang tua lebih menyuruh anaknya bekerja setelah mereka lulus sekolah dibandingkan dengan melanjutkan pendidikan ke perguruan tinggi supaya bisa membantu dalam memenuhi kebutuhan keluarga sehari-hari. Menurut Dalyono (2012) yang menyatakan, "Orang tua yang tidak/kurang memperhatikan pendidikan anaknya, mungkin acuh tak acuh, tidak memperhatikan kemajuan belajar anakanaknya akan menjadi penyebab kesulitan belajarnya". 
p-ISSN : 2599-1418

e-ISSN : 2599-1426

\section{d. Faktor Lokasi}

Seorang anak yang hidup dengan keadaan ekonomi yang pas-pasan dalam keluarganya akan sulit dalam menempuh perjalanan dari rumahnya menuju sekolah, sedangkan dirumah alat transportasi sangat terbatas. Hal tersebut sangat membebani orangtua yang tingkat ekonominya rendah, sehingga dengan terpaksa membiarkan anaknya sampai tidak melanjutkan pendidikannya ke perguruan tinggi. Berdasarkan hasil penelitian senada dengan pendapat Rifa'l (2011) menyatakan "Selain persoalan ekonomi yang menyebabkan banyak anak putus sekolah, yaitu berkaitan dengan susahnya mengakses sekolah karena persoalan jarak yang jauh. Hal itu kebanyakan terjadi di wilayah terpencil".

e. Faktor Lingkungan

Menurut Slameto (2010), mengatakan kehidupan masyarakat disekitar siswa juga berpengaruh terhadap belajar siswa. Masyarakat yang terdiri dari orang-orang yang tidak terpelajar, penjudi, suka mencuri dan mempunyai kebiasaan yang tidak baik, akan berpengaruh jelek kepada anak yang berada disitu". Hal tersebut dialami oleh saudari Via, dia tidak boleh melanjutkan pendidikannya ke perguruan tinggi dikarenakan ketakutan orangtuanya akan biaya yang dikeluarkan untuk membiayai kuliah sangat mahal dan hanya akan menambah beban keluarga seperti yang dialami oleh tetangganya.

2. Faktor Dominan Penyebab Kurangnya Minat Anak Keluarga Nelayan Melanjutkan Pendidikan ke Perguruan Tinggi

Dari hasil penelitian keenam orang tua dari anak yang tidak melanjutkan ke perguruan tinggi serta masyarakat sekitar di Desa Puger Kulon, dapat peneliti simpulkan bahwa faktor dominan yang menjadi penyebab kurangnya minat anak keluarga nelayan melanjutkan pendidikan ke perguruan tinggi yaitu faktor ekonomi keluarga, bagi orang tua yang mempunyai keterbatasan ekonomi akan mengalami kesulitan dalam membiayai pendidikan anaknya untuk melanjutkan ke perguruan tinggi. Sejalan dengan Zakir dalam Mardianti (2015) faktor yang menjadi penyebab remaja tidak melanjutkan
Jurnal Pendidikan Ekonomi Undiksha

Vol. 13 No. 2 (2021)

pendidikan yaitu: "Faktor ekonomi, kondisi ekonomi keluarga merupakan faktor pendukung paling besar untuk pendidikan anak, sebab pendidikan sangat membutuhkan biaya yang besar".

\section{SIMPULAN}

Dari hasil penelitian mengenai faktor penyebab kurangnya minat anak keluarga nelayan melanjutkan pendidikan ke perguruan tinggi di desa Puger Kulon Kecamatan Puger, maka kesimpulan yang dapat di ambil adalah sebagai berikut:

1. Faktor-Faktor Penyebab Kurangnya Minat Anak Keluarga Nelayan Melanjutkan Pendidikan Ke Perguruan Tinggi

Berdasarkan hasil penelitian dapat disimpulkan bahwa faktor penyebab kurangnya minat anak keluarga nelayan melanjutkan pendidikan ke perguruan tinggi ada lima pertama tidak ada keinginan dalam diri anak tersebut untuk melanjutkan pendidikan ke perguruan tinggi, kedua faktor ekonomi keluarga sehingga tidak dapat membiayai pendidikan anak untuk melanjutkan pendidikan ke perguruan tinggi. Ketiga tidak ada dorongan dari orangtua untuk melanjutkan pendidikan ke perguruan tinggi karena orangtua setelah anaknya lulus dari sekolah langsung menyuruh untuk mencari pekerjaan, keempat faktor lokasi anak yang hidup dengan keadaan ekonomi yang pas-pasan dalam keluarganya akan sulit dalam menempuh perjalanan dari rumahnya menuju sekolah, sedangkan dirumah alat transportasi sangat terbatas. Hal tersebut sangat membebani orangtua yang tingkat ekonominya rendah, sehingga dengan terpaksa membiarkan anaknya sampai tidak melanjutkan pendidikannya ke perguruan tinggi, kelima faktor lingkungan juga dapat mempengaruhi tingkat pendidikan anak, jika ditempat tinggalnya banyak yang hanya lulusan SMA atau SMK sudah bisa mendapatkan pekerjaan, maka lingkungan akan membentuknya seperti itu. 
p-ISSN : 2599-1418

e-ISSN : 2599-1426

2. Faktor Dominan Penyebab Kurangnya Minat Anak Keluarga Nelayan Melanjutkan Pendidikan Ke Perguruan Tinggi

Faktor paling dominan yang melatarbelakangi penyebab anak keluarga nelayan tidak bisa melanjutkan pendidikan ke perguruan tinggi di Desa Puger Kulon Kecamatan Puger adalah faktor ekonomi keluarga, bagi orang tua yang mempunyai keterbatasan ekonomi akan mengalami kesulitan dalam membiayai pendidikan anaknya untuk melanjutkan ke perguruan tinggi. Ketidakmampuan orang tua dalam membiayai kebutuhan pendidikan anaknya akan berdampak pada kelangsungan pendidikan anak, sehingga para orangtua hanya bisa menyekolahnya anaknya sampai tingkat SMA atau SMK saja.

\section{DAFTAR PUSTAKA}

Alexander, V. (2016). Persepsi Anak Nelayan Terhadap Pendidikan Resmi di Kenagarian Pasar Lama Kecamatan Linggo Sari Baganti Kabupaten Pesisir Selatan. Pendidikan Sejarah.

Arnawan, G. (2016). Faktor Penyebab Kurangnya Minat Remaja Desa Terhadap Pendidikan di Perguruan Tinggi (Studi Pada Remaja di Desa Balirejo Kecamatan Angkona Kabupaten Luwu Timur. Universitas Negeri Makassar.

Coombs, P. H. (1982). Apakah Perencanaan Pendidikan Itu. Jakarta: Bhatara Karya Aksara.

Dalyono, M. (2012). Psikologi Pendidikan. Jakarta: Rineka Cipta.

Hasbullah. (2012). Dasar-Dasar IImu Pendidikan. Jakarta: Rajawalipers.

Mardianti, D. (2015). Faktor Penyebab Remaja Tidak Melanjutkan Pendidikan Sampai Keperguruan Tinggi Di Pasir Kandang Kecamatan Koto Tengah Kota Padang. Lubuk Alung: STKIP YDB.

Miles, B. M., \& Houberman, A. M. (1992). Analisis Data Kualitatif. Jakarta: UI Press.

Palupi, E. P. D. (2017). Analisis Deskriptif Faktor Yang Mempengaruhi Rendahnya Minat Melanjutkan
Jurnal Pendidikan Ekonomi Undiksha

Vol. 13 No. 2 (2021)

Pendidikan Ke Perguruan Tinggi Pada Siswa Kelas XII SMK Negeri Karangpucung Kabupaten Cilacap. Universitas Negeri Semarang.

Rifa'l, M. (2011). Sosiologi Pendidikan. Jogjakarta: Ar-Ruzz Media.

Saroni, M. (2011). Orang Miskin Bukan Orang Bodoh. Yogyakarta: Bahtera Buku.

Slameto. (2010). Belajar Dan Faktor-Faktor Yang Mempengaruhi. Bandung: Rineka Cipta.

Sukardi. (2007). Metodologi Penelitian Pendidikan. Yogyakarta: Bumi Aksara.

Umbara, C. (2003). Undang-Undang RI no. 20 Tahun 2003 Tentang Sistem Pendidikan Nasional. Bandung: Citra Umbara.

Zakir, T. (2013). Faktor-Faktor Yang Menyebabkan Remaja Putus Sekolah Di Desa Tabongo Kecamatan Dulupi Kabupaten Boalemo. 